\title{
The surgical significance of methaemalbuminaemia
}

\author{
CAMERON BATTERSBY AND MARJORIE K. GREEN \\ From the Department of Surgery, University of Queensland, and Royal Brisbane Hospital, Brisbane, Australia
}

SUMMARY A quantitative estimation of plasma methaemalbumin can be useful. In pancreatitis, it usually indicates severe and haemorrhagic disease, and is thus of prognostic importance, as well as indicating the need for the full therapeutic regime for conservative management of the disease.

It may be helpful diagnostically in some patients with pancreatitis in whom it remains elevated after the serum amylase has returned to normal.

Raised levels may indicate laparotomy in patients in whom the diagnosis of pancreatitis is considered but who are not responding to conservative measures. Such patients may occasionally be suffering from intestinal infarction or other surgically remediable condition.

However, it has been found that the level of methaemalbumin in the plasma may be raised above the upper limit of the normal range of $5.5 \mathrm{mg} \%$ in occasional cases of gastrointestinal bleeding and soft tissue trauma and is not always raised in haemorrhagic pancreatitis.

Northam, Rowe, and Winstone (1963) suggested that the presence of a raised level of methaemalbumin in the plasma may be helpful in the differential diagnosis between haemorrhagic and oedematous pancreatitis. About the same time, a spectrometric method yielding quantitative results was described for methaemalbumin estimation in plasma (Shinowara and Walters, 1963) to supplement the older methods of direct spectroscopic examination, the Schumm reaction, and paper electrophoresis (Winstone, 1965).

Breakdown of haemoglobin in the presence of proteolytic enzymes results in the formation of haematin (haem, methaem). Haematin liberated into the plasma binds with albumin (to form methaemalbumin) or with a $\beta_{1}$ globulin to form haemopexin (Aber and Rowe, 1960). In intravascular haemolysis, free haemoglobin liberated into the plasma is first selectively bound to an $\alpha_{1}$ globulin (haptoglobin) and it is not until there is no haptoglobin left available for binding that free haemoglobin is converted to haematin which binds with albumin to form methaemalbumin (Neale, Aber, and Northam, 1958). This is shown diagrammatically in Figure 1. When methaemalbuminaemia occurs as a result of massive intravascular haemolysis, haptoglobin is absent from the plasma, but is present when the raised levels of methaemalbumin are the result of haemorrhagic pancreatitis.

There have been occasional reports of methaemalbuminaemia with normal levels of haptoglobin in Received for publication 28 June 1971.

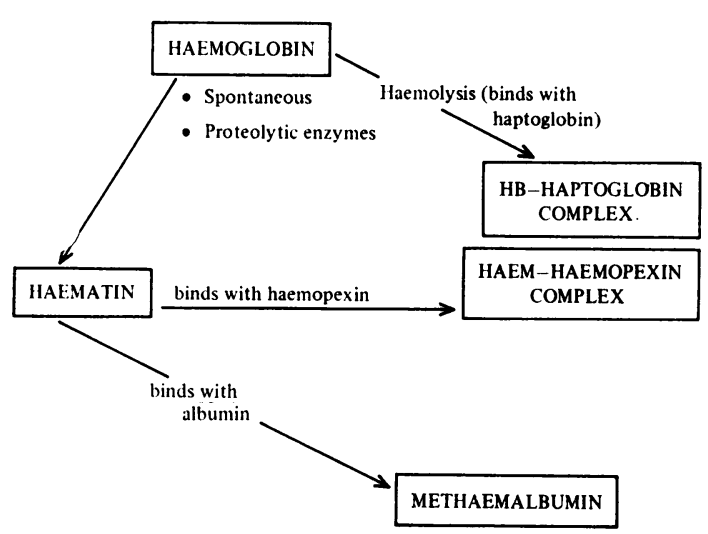

Fig. 1 Formation of methaemalbumin

the absence of haemorrhagic pancreatitis in ruptured ectopic pregnancy (Richardson, Glick, Bates, and Shinton, 1963) and scurvy and intraperitoneal haemorrhage (Northam, Winstone, and Banwell, 1965). Northam et al (1963) failed to detect methaemalbuminaemia in three cases with ruptured ectopic pregnancy, two with fractured femur, one with bleeding gastric ulcer, and one with traumatic intraabdominal haemorrhage. Experimental studies have shown that methaemalbuminaemia may occur in the dog in haemorrhagic pancreatitis (Joseph, Stevens, and Longmire, 1968) and also in intestinal 
infarction (Anderson, Toronto, Needleman, and Gramatica, 1969).

The study reported in this paper was designed to investigate levels of methaemalbumin in plasma in surgical states other than pancreatitis where haemoglobin might be expected to be exposed to proteolytic enzymes, and to compare these levels with those in a control group, and with a group with acute pancreatitis.

\section{Methods}

Four groups of patients were studied.

\section{CONTROLS}

These patients were admitted to hospital for a variety of conditions not causing acute abdominal symptoms. The patients suffered from hernia, varicose veins, skin lesions, breast lumps, peptic ulcer, gallstones in the quiescent phase, and cancer of the colon.

\section{ABDOMINAL PAIN, NOT PANCREATITIS}

In this group there were patients with intestinal obstruction, acute appendicitis, perforated peptic ulcer, and renal and biliary colic. These conditions had caused their emergency admission to hospital.

\section{HAEMORRHAGE AND TRAUMA}

These patients had massive gastrointestinal bleeding producing shock and requiring major transfusion, or major haemoperitoneum requiring operation. Those with trauma were suffering from fractured pelvis or femur or had large soft tissue haematomata without broken bones. Several had retroperitoneal haematomata following arterial surgery.

\section{ACUTE PANCREATITIS}

The criteria for inclusion of patients in this group were: (1) serum amylase greater than 500 Somogyi units in the presence of a clinical situation consistent with pancreatitis; (2) operative appearance; and (3) necropsy appearance.

Twenty $\mathrm{ml}$ of venous blood was collected from all patients shortly after their admission to hospital. Nine $\mathrm{ml}$ was placed in a centrifuge tube with $1 \mathrm{ml}$ of $4 \%$ sodium citrate and the remainder placed in a plain tube and allowed to clot. After centrifugation the plasma was collected and methaemalbumin estimated by the spectrometric method (Shinowara and Walters, 1963). Serum amylase was estimated by the micro method described by Wootton (1964) and expressed as Somogyi units (Somogyi, 1941). Serum haptoglobin was estimated by the method of Owen, Better, and Hoban (1960). Patients in whom levels of either amylase or methaemalbumin were raised were further studied by serial venepuncture usually daily initially, and then every two to three days.

\section{Results}

\section{CONTROLS (80 PATIENTS)}

The highest methaemalbumin level was $5.5 \mathrm{mg} / 100$ $\mathrm{ml}$, with a mean of $2.02 \mathrm{mg} / 100 \mathrm{ml} \pm 1.25 \mathrm{mg} / 100$ $\mathrm{ml}$ (standard deviation). Amylase levels in all patients were under 250 Somogyi units and haptoglobin was present in all patients.

\section{abdominal pain (130 patients)}

Serum amylase was not elevated to diagnostic levels in any of these patients and haptoglobins were present in all except one in whom the level of methaemalbumin was not raised. In three patients only were elevated levels of methaemalbumin found (Table I).

\begin{tabular}{|c|c|c|c|c|c|}
\hline Initials & $\begin{array}{l}\text { Age } \\
(y r)\end{array}$ & $\begin{array}{l}\text { Methaem- } \\
\text { albumin } \\
(\mathrm{mg} / 100 \mathrm{ml})\end{array}$ & $\begin{array}{l}\text { Amylase } \\
\text { (Somogyi } \\
\text { units) }\end{array}$ & $\begin{array}{l}\text { Hapto- } \\
\text { globin } \\
(\mathrm{mg} / 100\end{array}$ & $\begin{array}{l}\text { Diagnosis } \\
m l)\end{array}$ \\
\hline J.B. ${ }^{1}$ & 29 & $\begin{array}{ll}1 & 6 \cdot 9 \\
2 & 6 \cdot 1 \\
3 & 5 \cdot 3 \\
4 & 2 \cdot 7 \\
5 & 2 \cdot 2\end{array}$ & $\begin{array}{cc}1 & 84 \\
2 & 155 \\
3 & - \\
4 & 210 \\
5 & 80\end{array}$ & $\begin{array}{r}165 \\
36 \\
22 \\
40\end{array}$ & $\begin{array}{l}\text { Abdominal pain } \\
\text { undiagnosed }\end{array}$ \\
\hline E.S. & 91 & 9 & 224 & 123 & $\begin{array}{l}\text { Strangulated } \\
\text { small gut } \\
\text { obstruction }\end{array}$ \\
\hline L.G. & 82 & 9 & 88 & 144 & $\begin{array}{l}\text { Irreducible } \\
\text { hernia } \\
\text { ? pancreatitis }\end{array}$ \\
\hline
\end{tabular}

Table I Plasma methaemalbumin in abdominal pain, not proven pancreatitis

${ }^{1}$ The serial results for patient J.B. represent levels on successive days after initial admission.

\section{J.B. (aged 29)}

This young man had a high alcohol intake and clinically could have had pancreatitis although the amylase was not diagnostically elevated on his admission to hospital after several days of pain. The highest level of plasma methaemalbumin attained was $6.9 \mathrm{mg} / 100 \mathrm{ml}$ shortly after his admission to hospital when the serum amylase was 84 Somogyi units.

\section{E.S. (aged 91)}

This patient had a methaemalbumin level of $9 \mathrm{mg} / 100$ $\mathrm{ml}$ shortly before laparotomy for strangulated small gut obstruction. At operation there was no evidence of pancreatitis.

L.G. (aged 82)

The patient had a methaemalbumin level of $9 \mathrm{mg} / 100$ 
$\mathrm{ml}$ with a serum amylase of 88 Somogyi units and serum haptoglobin of $144 \mathrm{mg} / 100 \mathrm{ml}$. She underwent repair of an incarcerated right femoral hernia for recurrent vomiting. The abdomen was not opened and she died suddenly two days after operation. A necropsy was not allowed. In retrospect, it seems unlikely that the femoral hernia was the cause of her death which could possibly have been due to undiagnosed pancreatitis.

TRAUMA (60 PATIENTS)

In eight cases, abnormal levels of methaemalbumin were found. These results are set out in Table II.

\begin{tabular}{|c|c|c|c|c|}
\hline Patient & Diagnosis & $\begin{array}{l}\text { Maximum } \\
\text { Methaem- } \\
\text { albumin } \\
(\mathrm{mg} / 100 \mathrm{ml})\end{array}$ & $\begin{array}{l}\text { Amylase } \\
\text { (Somogyi } \\
\text { units) }\end{array}$ & $\begin{array}{l}\text { Timeafter } \\
\text { Onset of } \\
\text { Disease (days) }\end{array}$ \\
\hline
\end{tabular}

\begin{tabular}{|c|c|c|c|c|}
\hline \multirow{2}{*}{$\begin{array}{l}\text { E.P. } \\
\text { G.S. }\end{array}$} & $\begin{array}{l}\text { Upper abdominal } \\
\text { trauma }\end{array}$ & 8 & 97 & 6 \\
\hline & Retroperitoneal & & & \\
\hline F.M. & $\begin{array}{l}\text { Bleeding gastric } \\
\text { ulcer }\end{array}$ & $\begin{array}{r}11 \\
7.5\end{array}$ & $\begin{array}{l}40 \\
36\end{array}$ & 2 \\
\hline $\begin{array}{l}\text { J.S. } \\
\text { T.O'S. }\end{array}$ & $\begin{array}{l}\text { Spinal fracture } \\
\text { Fractured femur, }\end{array}$ & 6 & 70 & 7 \\
\hline & fractured spine & 9 & 244 & 3 \\
\hline $\begin{array}{l}\text { C.T. } \\
\text { N.Q. }\end{array}$ & $\begin{array}{l}\text { Fractured pelvis } \\
\text { Vascular(popliteal } \\
\text { artery)injury- } \\
\text { multiple major } \\
\text { bruising of soft }\end{array}$ & $1^{7 \cdot 5}$ & 77 & 7 \\
\hline M.S. & $\begin{array}{l}\text { tissue } \\
\text { Ruptured aortic }\end{array}$ & 12 & 210 & 6 \\
\hline & aneurysm & 8 & 77 & 4 \\
\hline
\end{tabular}

Table II Plasma methaemalbumin (maximum levels) in haemorrhage and trauma
The rise and fall of methaemalbumin levels in one patient (N.Q.) who suffered from severe vascular and soft tissue trauma of the lower limbs is shown in Figure 2.

\section{PANCREATITIS (21 PATIENTS)}

Elevated plasma levels of methaemalbumin have been found in five patients and these are presumed to have been suffering from haemorrhagic pancreatitis. Laparotomy or necropsy proof of the presence of haemorrhagic pancreatitis was available in two of these patients. In addition, a further two patients were shown at laparotomy to have acute haemorrhagic pancreatitis, but the methaemalbumin levels were within the normal range. Of these seven patients with haemorrhagic pancreatitis, four died and three recovered. The other 14 patients in the group all had amylase levels in excess of 500 Somogyi units to fulfil the criteria set out above. All recovered on conservative management. Haptoglobin was present in the sera of all patients. Details of the four patients with acute haemorrhagic pancreatitis proven at laparotomy are shown in Table III.

Serial levels of methaemalbumin for the patient B.D., who was studied in detail, are shown in Figure 3. On admission to hospital this patient had a markedly raised amylase level of 1,300 Somogyi units and a raised methaemalbumin of $13.5 \mathrm{mg} / 100 \mathrm{ml}$. Following a clinical deterioration, a laparotomy was performed and haemorrhagic pancreatitis was found. The serum amylase at this stage had fallen to 440 Somogyi units but the methaemalbumin remained at $13.5 \mathrm{mg} / 100 \mathrm{ml}$; the level subsequently

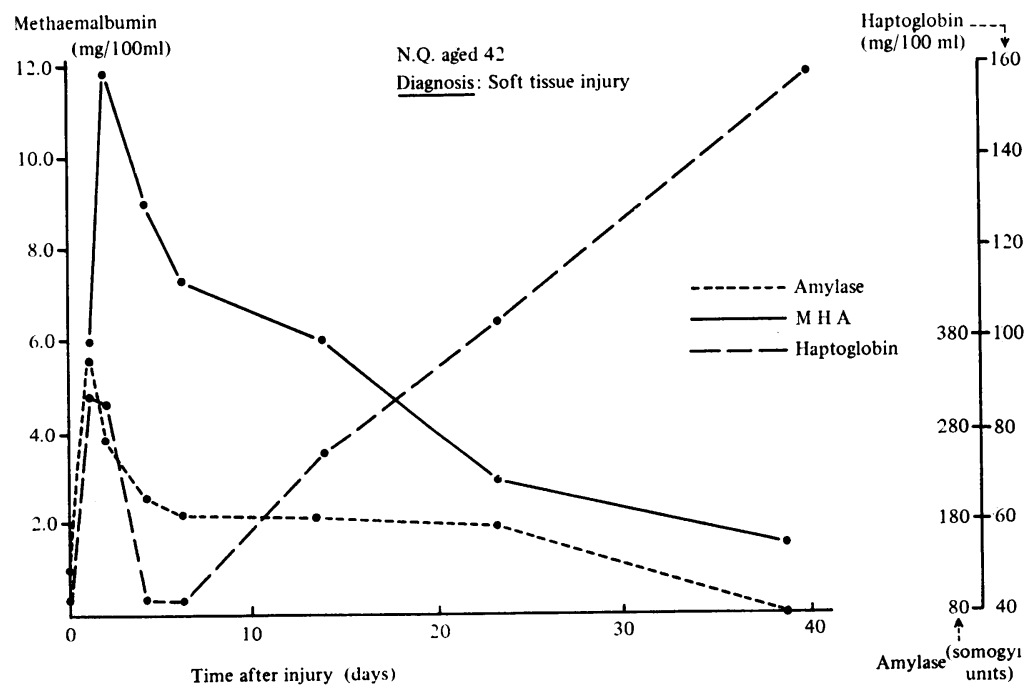

Fig. 2 Progressive levels plasma $M H A$, serum haptoglobin, and serum amylase in a patient with a severe soft tissue injury. 


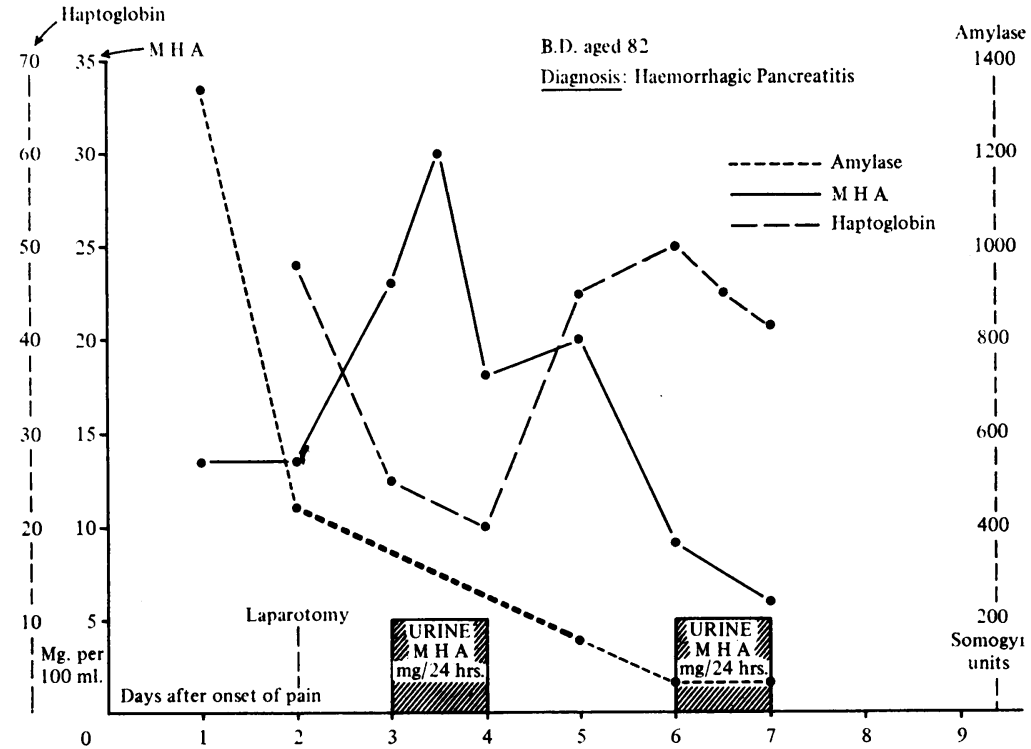

Fig. 3 Progressive levels of plasma $M H A$, serum haptoglobin, and serum amylase in a patient with acute haemorrhagic pancreatitis.

\begin{tabular}{lllll}
\hline $\begin{array}{l}\text { Dayafter } \\
\text { Operation }\end{array}$ & \multicolumn{4}{l}{ Methaemalbumin $(\mathrm{mg} / 100 \mathrm{ml})$} \\
\cline { 2 - 5 } & B.D. & L.C. & A.Z. & E.C. \\
\hline 1 & $13 \cdot 5$ & - & - & $7 \cdot 8$ \\
2 & 30 & - & - & Died \\
3 & 18 & $1 \cdot 2$ & -0 & \\
4 & 20 & - & - & \\
5 & 9 & - & - & \\
6 & 6 & $2 \cdot 1$ & 3.0 & \\
\hline
\end{tabular}

Table III Plasma methaemalbumin in acute haemorrhagic pancreatitis (proven at laparotomy) ${ }^{1}$

${ }^{1}$ No patient had more than $\mathbf{4 8}$ hours' history of pain preoperatively.

rose to $30 \mathrm{mg} / 100 \mathrm{ml}$, and on the third day after operation when the amylase level was normal the methaemalbumin was still raised at $20 \mathrm{mg} / 100 \mathrm{ml}$. Unfortunately, the serum amylase levels in the intervening period are not available.

\section{Discussion}

We have studied 80 patients suffering from miscellaneous surgical conditions not causing acute abdominal pain and have not, so far, found methaemalbumin levels over $5.5 \mathrm{mg} / 100 \mathrm{ml}$. We are not aware of any previous report in the literature of a survey of methaemalbumin levels in a large number of control patients using the quantitative method of estimation described by Shinowara and Walters (1963).

Despite the recent introduction of this quantitative method of estimation most results have still been expressed in terms of trace,,+++ , and +++ respectively (Winstone, 1965). Joseph et al (1968) estimated methaemalbumin in five control dogs which did not have a surgical operation and found levels between 4.01 and $8.0 \mathrm{mg} / 100 \mathrm{ml}$. Dogs which underwent exploratory laparotomy and no other procedure had methaemalbumin levels between 4.5 and $7.8 \mathrm{mg} / 100 \mathrm{ml}$. Methaemalbumin levels, therefore, in these dogs were not greater than $8 \mathrm{mg} / 100 \mathrm{ml}$. It is interesting to speculate on the origin of the levels of methaemalbumin present in normal subjects. Presumably, some methaemalbumin may be formed by the action of proteolytic enzymes on blood entering the gastrointestinal tract although there appears to be no information on the absorption of methaemalbumin from the gut. It may also be possible that some haemoglobin is liberated from red cell breakdown in the tissues and that some haemoglobin liberated intravascularly escapes the binding by haptoglobin despite the avidity of haptoglobin for free haemoglobin.

Raised levels of methaemalbumin in a wide variety of acute abdominal conditions other than haemorrhagic pancreatitis have not been found, but a level of $9 \mathrm{mg} / 100 \mathrm{ml}$ was present in a patient with strangulated intestinal obstruction. It may sometimes be a matter of extreme difficulty to be certain of the diagnosis of pancreatitis and if the diagnosis is at all in doubt a raised level of methaemalbumin in the plasma may be an indication for diagnostic laparotomy to eliminate strangulated obstruction. That laparotomy is not always harmful in pancreatitis 
and may, in fact, save lives in cases of mistaken diagnosis has been shown by Trapnell and Anderson (1967). Winstone (1965) showed that methaemalbumin-positive cases of acute pancreatitis had a similar incidence of gallstones to the negative cases but where methaemalbumin was positive there were three times the number of patients with stones in the bile duct. Such patients may possibly benefit from earlier operation and duct drainage although it may be argued that once haemorrhagic pancreatitis has occurred the damage has been done and operative intervention cannot reverse the situation.

However, the variable and often scattered areas of haemorrhage in the pancreas, together with the occasional marked worsening of the disease during its course, suggest that attempts at halting of progress of the disease may be worthwhile.

A number of patients have been found to have raised levels of methaemalbumin in the plasma following gastrointestinal haemorrhage or major soft tissue trauma. These levels have sometimes been apparent within 48 hours of the onset of the pathology, although the maximum levels have often been attained as late as seven days after onset. Northam et al (1963) showed that in acute pancreatitis traces of methaemalbumin were sometimes present at about 12 hours after the onset of the disease and that maximum levels were usually found between four and six days later. They contrasted this timing in haemorrhagic pancreatitis with that following haematoma absorption where the appearance of methaemalbumin was much later. Our experience, therefore, has not been completely in accord with theirs. It does appear, however, that absorption of blood from large haematomata in soft tissues may cause raised levels of methaemalbumin in the plasma. This may result from liberation of proteolytic enzymes from damaged tissues and cells in the vicinity of the haematoma which subsequently break down haemoglobin from red cells in the haematoma. The haptoglobin levels in these patients have been within normal limits indicating that the cause of the methaemalbuminaemia is not only intravascular haemolysis.

It is, however, in the diagnosis, prognosis, and management of acute pancreatitis that raised levels of methaemalbumin hold most interest. Diagnostically it appears that methaemalbuminaemia in most cases indicates haemorrhagic pancreatitis. However, there are some qualifications because raised levels of methaemalbumin are also present in strangulated intestinal obstruction. In doubtful cases, the presence of methaemalbuminaemia may thus be an indication for a diagnostic laparotomy. We have also shown that on several occasions methaemalbumin levels have been raised when serum amylase is within normal limits. This may be useful, particularly when the patient is seen for the first time three or four days after the onset of the illness. At this time the serum amylase which was formerly elevated has often returned to normal limits while the plasma methaemalbumin level is still rising (Northam et al, 1963).

It is well known (Elman, 1946; Siler, Wulsin, and Carter, 1955; Trapnell, 1966) that the mortality rate with acute haemorrhagic pancreatitis is between 30 and $50 \%$, while that for the oedematous variety is of the order of $6 \%$ (Winstone, 1965). Our results support this. We have had no deaths in patients with oedematous pancreatitis, but four of the seven patients with haemorrhagic pancreatitis died. As it is very difficult to use any other criterion than death in assessing the effect of treatment for pancreatitis, methaemalbuminaemia may indicate which patients should be selected for any projected trials of a new method of treatment.

It is interesting to speculate on the reason for the normal methaemalbumin level in the two patients who were proven at laparotomy to have haemorrhagic disease. This has been noted before (Winstone, 1965).

Patients L.C. and A.Z. (Table III) had operations proving haemorrhagic pancreatitis and when methaemalbumin was estimated two days after laparotomy the levels were within normal limits. It may be argued that the levels had previously been raised, but that this elevation had been missed in the time between laparotomy and first estimation. However, as has been shown by Northam et al (1963), raised levels of methaemalbumin appear after about 12 hours from the onset of the disease and are maximum at about four days. It therefore seems unlikely that the level of methaemalbumin in the plasma had fallen to normal after being elevated at the time of laparotomy. There is a spectrum of pancreatic reaction to insult from all sorts of different causes varying from pancreatic oedema to frank haemorrhage and it is quite likely that small foci of haemorrhage in a predominantly oedematous gland will produce lower levels of methaemalbumin than when there is complete haemorrhagic necrosis of the pancreas.

\section{References}

Aber, G. M., and Rowe, D. S. (1960). The binding of haematin by serum proteins. Brit. J. Haemat., 6, 160-165.

Anderson, M. C., Toronto, I. R., Needleman, S. B., and Gramatica, L. (1969). Assessment of methemalbumin as a diagnostic test for acute pancreatitis. Arch. Surg., 98, 776-780.

Elman, R. (1946). Surgery in acute pancreatitis. Gastroenterology, 7, 656-664.

Joseph, W. L., Stevens, G. H., and Longmire, W. P., Jr. (1968). Methemalbumin in the diagnosis of acute pancreatitis. J. surg. Res., 8, 206-210. 
Neale, F. C., Aber G. M., and Northam, B. E. (1958). The demonstration of intravascular haemolysis by means of serum paper electrophoresis and a modification of Schumm's reaction. J. clin. Path., 11, 206-219.

Northam, B. E., Rowe, D. S., and Winstone, N. E. (1963). Methaemalbumin in the differential diagnosis of acute haemorrhagic and oedematous pancreatitis. Lancet, 1, 348-352.

Northam, B. E., Winstone, N. E., and Banwell, J. G. (1965). Biochemi$\mathrm{cal}$ aspects of pancreatitis. In Recent Advances in Gastroenterology, edited by J. Badenoch and B. N. Brooke, pp. 349-373. Churchill, London.

Owen, J. A., Better, F. C., and Hoban, J. (1960). A simple method for the determination of serum haptoglobins. J. clin. Path., 13, 163-164.

Richardson, R. W., Glick, S., Bates, A., and Shinton, N. K. (1963). Methaemalbumin in the diagnosis of pancreatitis. Lancet, 1 , 608-609.
Shinowara, G. Y., and Walters, M. I. (1963). Hematin-studies on protein complexes and determination in human plasma. Amer. J. clin. Path., 40, 113-122.

Siler, V. E., Wulsin, J. H., and Carter, B. N. (1955). Important clinical factors of acute pancreatitis. Surg. Gynec. Obstet., 100, 357-365.

Somogyi, M. (1941). Diastatic activity of human blood. Arch. intern. Med., 67, 665-679.

Trapnell, J. E. (1966). The natural history and prognosis of acute pancreatitis. Ann. roy. Coll. Surg. Engl., 38, 265-287.

Trapnell, J. E. and Anderson, M. C. (1967). Role of early laparotomy in acute pancreatitis. Ann Surg., 165, 49-55.

Winstone, N. E. (1965). Methaemalbumin in acute pancreatitis. Brit. J. Surg., 52, 804-808.

Wootton, I. D. P. (1964). Micro-analysis in Medical Biochemistry, 4th ed., p. 106. Churchill, London. 